\title{
GENETIC STUDIES ON RHEUMATOID ARTHRITIS
}

\author{
BY
}

\author{
J. S. LAWRENCE AND J. BALL
}

From the Empire Rheumatism Council Field Unit and Rheumatism Research Centre, University of Manchester

Though there has been much speculation on the causes of rheumatoid arthritis, the fundamental mechanism remains obscure. There have, however, been indications that a hereditary factor is present (Falls, 1953). Kroner reported four generations of rheumatoid arthritis in one family, the disease being apparently transmitted by the females. Papp and Tepperberg (1937), in another family, recorded eleven persons with rheumatoid arthritis in four generations. Kaufmann and Scheerer (1928) found a greater concordance in monozygotic than in dizygotic twins. Short, Abrams, and Sartwell (1952) recorded a prevalence of 12 per cent. in rheumatoid arthritic families, but of only 5 per cent. in controls and in the series of Stecher, Solomon, and Wolpaw (1952), the prevalence was 5 and 0.1 per cent. in rheumatoid families and controls respectively. In the Empire Rheumatism Council's Report on aetiological factors in rheumatoid arthritis (Lewis-Faning, 1950), 7 per cent. of the fathers of patients as compared with 3 per cent. of the fathers of controls and 15 per cent. of the mothers of patients as opposed to 9 per cent. of the mothers of controls had arthritis. For siblings the figures were 4 per cent. against 2 per cent. Similar figures were obtained by Barter (1952) in a comparison of the family histories of 100 rheumatoids with 100 controls who were non-rheumatic hospital patients. Miall (1955) noted a prevalence of 3 per cent. in the parents and siblings of 59 males with rheumatoid arthritis taken from a population sample in South Wales, but only 0.6 per cent. in the parents and siblings of controls of the same age, taken at random from the local population. De Blécourt (1957) examined over 2,000 relatives of persons with rheumatoid arthritis and a similar number of controls; prevalences ranged from 0.6 per cent. in male cousins to 10 per cent. in mothers of persons with rheumatoid arthritis (average $2 \cdot 3$ per cent.).
In the controls the prevalence of rheumatoid arthritis varied from 0.2 per cent. in male cousins to 3 per cent. in mothers (average 0.8 per cent.).

These figures, though they give clear evidence of a hereditary influence, do not indicate that this is very important, since the prevalence in other members of the family is not much greater than in the controls. Several factors may, however, have tended to obscure the genetic effect in these studies. Rheumatoid arthritis as diagnosed in the propositg may not have been homogeneous, but may have included a number of diseases with similar clinicats. features, only one of which had a genetic basis Furthermore, the disease in the hereditary form may be of low expressivity so that in its milder forms it is not recognized as such by the relatives of the rheumatoids, or it may indeed be completely symptomless. With a view to obtaining more definite information on these points a more detailed survey has been made of the families of persons found to have rheumatoid arthritis in the survey of rheumatic diseases in the town of Leigh, Lancashire.

\section{Method}

Persons considered to have definite clinical rheumatoid arthritis or who had a positive sheepcell test in a survey of those between the age of 55 and 64 in a random sample of the town of Leigh (Kellgren and Lawrence, 1956) were revisited, and a list was made of surviving parents, siblings, and children over the age of 14 . All those relatives living within a 10-mile radius of Leigh were then visited after an explanatory letter and questionnaire had been sent through the post. During this visit the questionnaire, which dealt with past and present rheumatic disorders, injury, and morning stiffness, was completed and arrangements were made for attendance at the centre for a detailed 
clinical and radiological examination of the skeletal system and the collection of a sample of blood for the sheep-cell test.

At the same time a 1 in 30 sample of households in Leigh was taken from the electoral roll to serve as a control group. All those over the age of 14 years in these households were asked to attend the centre. The initial approach and the subsequent examination at the centre was identical in the rheumatoid families and the controls and appointments from each group were intermingled. Any persons found to have clinical rheumatoid arthritis or a positive sheep-cell test in the random sample were also used as propositi in the families study. To obviate undue radiological hazard a complete $x$-ray examination was considered undesirable in the younger age groups. The scheme adopted is shown below:

\begin{tabular}{c|c}
\hline Age (yrs) & \multicolumn{1}{|c}{ Parts $X$-Rayed } \\
\hline $55+$ & $\begin{array}{c}\text { Hands, feet, cervical spine, lumbar spine, } \\
\text { knees, pelvis }\end{array}$ \\
\hline $35-54$ & $\begin{array}{l}\text { Hands, feet, cervical spine, lumbar spine, } \\
\text { knees }\end{array}$ \\
\hline-34 & Hands, feet, cervical spine \\
\hline
\end{tabular}

Antero-posterior views only were taken of the hands, feet, knees, and pelvis, and lateral views only of the cervical and lumbar spine.

Those persons who were unable or unwilling to come to the centre were examined at home. Owing to the limitations of portable equipment for home visits, $x$ rays of the lumbar spine and pelvis had to be omitted in these cases, but the examination was otherwise identical with that carried out at the centre.
All $x$ rays were read by one of us (J.S.L.), and were graded for osteoporosis, erosions, rheumatoid arthritis, and osteo-arthrosis. The spinal films were also graded for disk degeneration. Five grades of severity* were used: $0=$ None; $1=$ Doubtful; $2=$ Minimal; $3=$ Moderate; $4=$ Severe.

The system of reference numbers was so arranged that it was impossible for the examiner to tell, when reading the $x$ rays, whether they belonged to the rheumatoid families or the controls, and no clinical or serological information was available to him at the time. Thus any bias on the part of the examiner can be excluded. This also applies to readings of the sheep-cell test, but not to the clinical examination.

Completeness of Survey.-Of 209 relatives of persons with rheumatoid arthritis living within the area (Table I), 183 (87 per cent.) were examined. Of 963 persons who comprised the random sample, 822 (85 per cent.) were examined. The response rate was thus similar in these two samples. The examination was complete in 95 per cent. of those examined in the rheumatoid families, but in 2 per cent. no blood test was available and in 3 per cent. $x$ rays were refused. In the random sample, the corresponding figures were 95 per cent., 5 per cent., and 1 per cent.

Composition of Rheumatoid Family Sample.-The propositi were 67 in number $(21$ males and 43 females: Table I). The preponderance of females was practically confined to the group with clinical rheumatoid arthritis only. Those with a positive sheep-cell test, whether with or without clinical rheumatoid arthritis, were fairly equally distributed between the sexes. The age distribution of the propositi ranged between 43 and 78 years in the

* For a more detailed definition of these gradings see Kellgren and Lawrence (1957).

TABLE I

COMPLETENESS OF SURVEY

\begin{tabular}{|c|c|c|c|c|c|c|c|c|}
\hline \multirow[b]{2}{*}{ Sample } & & \multirow{2}{*}{$\begin{array}{c}\text { Total } \\
\text { in } \\
\text { Sample }\end{array}$} & \multirow{2}{*}{$\begin{array}{c}\text { Not Available } \\
\text { or Refused } \\
\text { All Examinations }\end{array}$} & \multicolumn{2}{|c|}{ Total Examined } & \multicolumn{3}{|c|}{ Examinations Performed } \\
\hline & & & & No. & $\begin{array}{l}\text { Percentage } \\
\text { of Total } \\
\text { Sample }\end{array}$ & $\begin{array}{c}\text { Clinical, } \\
X \text { Ray, and } \\
\text { Blood Test }\end{array}$ & $\begin{array}{l}\text { Clinical } \\
\text { and } X \text { Ray } \\
\text { Only }\end{array}$ & $\begin{array}{l}\text { Clinical } \\
\text { and Blood } \\
\text { Test Only }\end{array}$ \\
\hline \multirow[t]{2}{*}{ Relatives of Propositi } & $\begin{array}{l}\text { Men } \\
\text { Women }\end{array}$ & $\begin{array}{l}101 \\
108\end{array}$ & $\begin{array}{l}14 \\
12\end{array}$ & $\begin{array}{l}87 \\
96\end{array}$ & $\begin{array}{l}86 \\
89\end{array}$ & $\begin{array}{l}83 \\
92\end{array}$ & $\begin{array}{l}1 \\
2\end{array}$ & $\begin{array}{l}3 \\
2\end{array}$ \\
\hline & Total & 209 & 26 & 183 & 87 & 175 & 3 & 5 \\
\hline \multirow[t]{2}{*}{ Random Sample } & $\begin{array}{l}\text { Men } \\
\text { Women }\end{array}$ & $\begin{array}{l}474 \\
489\end{array}$ & $\begin{array}{l}65 \\
76\end{array}$ & $\begin{array}{l}409 \\
413\end{array}$ & $\begin{array}{l}86 \\
84\end{array}$ & $\begin{array}{l}391 \\
384\end{array}$ & $\begin{array}{l}13 \\
26\end{array}$ & $\begin{array}{l}5 \\
3\end{array}$ \\
\hline & Total & 963 & 141 & 822 & 85 & 775 & 39 & 8 \\
\hline
\end{tabular}


TABLE II

AGE AND SEX OF PROPOSITI

\begin{tabular}{|c|c|c|c|c|c|c|c|c|c|c|c|c|c|c|c|c|c|}
\hline $\operatorname{Sex} \quad \ldots \quad \ldots$ & & & & & & & & & & & & & Female & & & & \\
\hline Age (yrs) & -24 & -34 & -44 & -54 & -64 & -74 & $75+$ & Total & -24 & -34 & -44 & -54 & -64 & -74 & $75+$ & Total & Total \\
\hline No. of Propositi & 0 & 0 & 1 & 2 & 12 & 5 & 1 & 21 & 0 & 2 & 2 & 5 & 31 & 2 & 1 & 43 & 64 \\
\hline
\end{tabular}

TABLE III

AGE AND SEX OF RELATIVES OF PROPOSITI WITH VARIOUS GRADES OF CLINICAL AND SEROLOGICAL RHEUMATOID ARTHRITIS

\begin{tabular}{|c|c|c|c|c|c|c|c|c|c|c|c|c|c|c|c|c|c|c|c|c|c|}
\hline \multicolumn{5}{|c|}{ Propositi } & \multicolumn{16}{|c|}{ Numbers of Relatives, by sex and age (yrs) } & \multirow{3}{*}{ Total } \\
\hline \multirow{2}{*}{$\begin{array}{c}\text { Sheep-Cell } \\
\text { Agglutination } \\
\text { Test }\end{array}$} & \multirow{2}{*}{$\begin{array}{c}\text { Clinical } \\
\text { Rheumatoid } \\
\text { Arthritis } \\
\text { Grading }\end{array}$} & \multirow{2}{*}{ M. } & \multirow{2}{*}{ F. } & \multirow{2}{*}{ Total } & \multicolumn{8}{|c|}{ Male } & \multicolumn{8}{|c|}{ Female } & \\
\hline & & & & & -24 & -34 & -44 & -54 & -64 & -74 & $75+$ & Total & -24 & -34 & -44 & -54 & -64 & -74 & $75+$ & Total & \\
\hline \multirow{2}{*}{ Negative } & $\begin{array}{c}\text { Moderate } \\
\text { or Severe }\end{array}$ & 3 & 5 & 8 & 3 & 1 & 0 & 1 & 6 & 2 & 0 & 13 & 2 & 1 & 1 & 2 & 2 & 2 & 0 & 10 & 23 \\
\hline & Minimal & 2 & 19 & 21 & 4 & 11 & 4 & 2 & 4 & 0 & 0 & 25 & 10 & 8 & 6 & 4 & 6 & 6 & 0 & 40 & 65 \\
\hline \multirow{3}{*}{ Positive } & $\begin{array}{l}\text { Moderate } \\
\text { or Severe }\end{array}$ & 4 & 6 & 10 & 2 & 3 & 1 & 1 & 3 & 2 & 0 & 12 & 0 & 4 & 0 & 5 & 3 & 3 & 0 & 15 & 27 \\
\hline & Minimal & 2 & 2 & 4 & 1 & 2 & 1 & 3 & 2 & 1 & 0 & 10 & 0 & 1 & 0 & 3 & 1 & 0 & 1 & 6 & 16 \\
\hline & $\begin{array}{l}\text { None or } \\
\text { Doubtful }\end{array}$ & 10 & 11 & 21 & 0 & 7 & 7 & 6 & 5 & 2 & 0 & 27 & 1 & 5 & 4 & 5 & 3 & 3 & 4 & 25 & 52 \\
\hline \multicolumn{2}{|c|}{ Totals } & 21 & 43 & 64 & 10 & 24 & 13 & 13 & 20 & 7 & 0 & 87 & 13 & 19 & 11 & 19 & 15 & 14 & 5 & 96 & 183 \\
\hline
\end{tabular}

males and 26 and 75 years in females. As those between the ages of 55 and 64 were taken from a larger sample of the population, they form a relatively large group of the propositi in both sexes and in no way reflect the true age distribution in the population (Table II).

Of the relatives examined, seven were parents, 95 siblings, and 81 offspring. The age and sex distribution of these relatives is as shown in Table III. In both sexes there were more young people in the families of those propositi who had a negative sheep-cell agglutination test. The control group from the random sample was matched for decade and sex with the rheumatoid relatives, but within each decade and sex was chosen at random.

\section{Results}

These have been assessed on the prevalence of clinical and radiological rheumatoid arthritis, on the sheep-cell titre, and finally on the American Rheumatism Association classification.

Clinical Studies.-Clinical rheumatoid arthritis (Grade 2-4) was encountered four times as often in the rheumatoid families as in the controls (Table IV, opposite).

The arthritis was also more severe, and the rheumatoid families had more persons with doubtful rheumatoid arthritis, but past polyarthritis was noto more frequent. The difference in the prevalence of Grade 2 to 4 rheumatoid arthritis between these two groups is highly significant $(P=<0 \cdot 01)$. Those families in which the propositus had both a positive sheep-cell test and clinical rheumatoid arthritis had a greater prevalence than any of the others, 16 per cent. of the relatives of these persons having definite clinical disease. The families of those with a negative sheep-cell test had a lower prevalence, but the most striking contrast is with the relatives of those with Grade 3-4 disease and a negative test, none of whom had definite clinical disease. The numbers in this group, however, are small and the difference is thus not significant $(P=0 \cdot 1)$. The propositi with a positive sheep-cell test but no clinical disease occupied an intermediate position, having one Grade 4 and one Grade 2 rheumatoid arthritic only in their families.

Radiological Studies.-Definite radiological evidence of rheumatoid arthritis (Table V, opposite) was found in 3 per cent. of the controls and in 7 per cent. of the rheumatoid families, the latter having more of the moderate or severe gradings $(P=0.06)$. As in the clinical study, the relatives of those with both clinical rheumatoid arthritis and a positive sheep-cell test had more rheumatoid disease than 
TABLE IV

PREVALENCE OF CLINICAL RHEUMATOID ARTHRITIS IN RELATIVES OF PROPOSITI AND IN CONTROLS

\begin{tabular}{|c|c|c|c|c|c|c|c|c|c|c|c|}
\hline \multicolumn{3}{|c|}{ Propositi } & \multicolumn{8}{|c|}{ Clinical Rheumatoid Arthritis Grading } & \multirow{2}{*}{$\begin{array}{l}\text { Group } \\
\text { Examined } \\
\text { for } \\
\text { Comparison }\end{array}$} \\
\hline $\begin{array}{l}\text { Sheep-cell } \\
\text { Agglutina- } \\
\text { tion } \\
\text { Test }\end{array}$ & $\begin{array}{l}\text { Clinical } \\
\text { Rheumatoid } \\
\text { Arthritis } \\
\text { Grading }\end{array}$ & No. & None & $\begin{array}{l}\text { Past } \\
\text { Poly- } \\
\text { Arth- } \\
\text { ritis } \\
\text { Only }\end{array}$ & $\stackrel{1}{\text { Doubtful }}$ & $\stackrel{2}{\text { Minimal }}$ & $\stackrel{3}{\text { Moderate }}$ & $\begin{array}{c}4 \\
\text { Severe }\end{array}$ & $\begin{array}{c}\text { Total } \\
\text { Examined }\end{array}$ & $\begin{array}{c}\text { Grade } 2-4 \\
\text { Minimal to } \\
\text { Severe } \\
\text { (Percentage } \\
\text { of total) }\end{array}$ & \\
\hline \multirow[t]{2}{*}{ Negative } & $\begin{array}{l}\text { Moderate or } \\
\text { or Severe .. }\end{array}$ & 8 & 12 & 2 & 9 & 0 & 0 & $\mathbf{0}$ & 23 & 0 & \multirow{7}{*}{$\begin{array}{l}\text { Relatives } \\
\text { of } \\
\text { Propositi }\end{array}$} \\
\hline & Minimal $\quad \ldots$ & 21 & 45 & 2 & 11 & 6 & 1 & $\mathbf{0}$ & 65 & 11 & \\
\hline \multirow{3}{*}{ Positive } & $\begin{array}{l}\text { Moderate or } \\
\text { Severe }\end{array}$ & 10 & 13 & 1 & 8 & 2 & 1 & 2 & 27 & 19 & \\
\hline & Minimal $\quad \ldots$ & 4 & 7 & 3 & 4 & 1 & 1 & 0 & 16 & 13 & \\
\hline & $\begin{array}{l}\text { None or } \\
\text { Doubtful ... }\end{array}$ & 21 & 34 & 0 & 16 & 1 & 0 & 1 & 52 & 4 & \\
\hline \multicolumn{2}{|c|}{$\begin{array}{l}\text { Total Propositi with Clinical } \\
\text { Rheumatoid Arthritis } \\
\text { Total Propositi with Positive } \\
\text { Sheep-cell Agglutination } \\
\text { Test }\end{array}$} & 43 & 54 & 4 & 32 & 4 & 2 & 3 & 131 & 11 & \\
\hline \multicolumn{2}{|c|}{ Total } & 64 & 111 & 8 & 48 & 10 & 3 & 3 & 183 & 9 & \\
\hline & - & & 152 & 12 & 15 & 3 & 0 & 1 & 183 & 2 & Controls \\
\hline
\end{tabular}

TABLE V

PREVALENCE OF RADIOLOGICAL RHEUMATOID ARTHRITIS IN HANDS AND FEET IN RELATIVES OF PROPOSITI AND IN CONTROLS

\begin{tabular}{|c|c|c|c|c|c|c|c|c|c|c|c|}
\hline \multicolumn{3}{|c|}{ Propositi } & \multicolumn{8}{|c|}{ Radiological Rheumatoid Arthritis Grading } & \multirow[b]{2}{*}{$\begin{array}{l}\text { Group } \\
\text { Examined } \\
\text { for } \\
\text { Comparison }\end{array}$} \\
\hline $\begin{array}{l}\text { Sheep-cell } \\
\text { Agglutina- } \\
\text { tion } \\
\text { Test }\end{array}$ & $\begin{array}{l}\text { Clinical } \\
\text { Rheumatoid } \\
\text { Arthritis } \\
\text { Grading }\end{array}$ & No. & None & $\begin{array}{l}\text { Doubt- } \\
\text { ful }\end{array}$ & Minimal & Moderate & Severe & $\begin{array}{c}\text { Total } \\
X \text { Rayed }\end{array}$ & $X \stackrel{\text { Not }}{\text { Rayed }}$ & $\begin{array}{c}\text { Minimal to } \\
\text { Severe } \\
\text { (Percentage } \\
\text { of total } \\
X \text { Rayed) }\end{array}$ & \\
\hline \multirow[t]{2}{*}{ Negative } & $\begin{array}{l}\text { Moderate or } \\
\text { Severe }\end{array}$ & 8 & 18 & 5 & $\mathbf{0}$ & 0 & $\mathbf{0}$ & 23 & $\mathbf{0}$ & 0 & \multirow{7}{*}{$\begin{array}{l}\text { Relatives } \\
\text { of } \\
\text { Propositi }\end{array}$} \\
\hline & Minimal $\ldots$ & 21 & 53 & 8 & 1 & $\mathbf{0}$ & $\mathbf{0}$ & 62 & 3 & 2 & \\
\hline \multirow{3}{*}{ Positive } & $\begin{array}{l}\text { Moderate or } \\
\text { Severe }\end{array}$ & 10 & 14 & 7 & 2 & $\mathbf{0}$ & 3 & 26 & 1 & 19 & \\
\hline & Minimal $\quad \ldots$ & 4 & 9 & 6 & 0 & 1 & $\mathbf{0}$ & 16 & 0 & 6 & \\
\hline & $\begin{array}{l}\text { None or } \\
\text { Doubtful ... }\end{array}$ & 21 & 38 & 8 & 3 & 2 & 0 & 51 & 1 & 10 & \\
\hline \multicolumn{2}{|c|}{$\begin{array}{l}\text { Total Propositi with Clinical } \\
\text { Rheumatoid Arthritis } \\
\text { Total Propositi with Positive } \\
\text { Sheep-cell Agglutination }\end{array}$} & 43 & 94 & 21 & 5 & 3 & 3 & 127 & 2 & 12 & \\
\hline \multicolumn{2}{|c|}{ Total } & 64 & 132 & 34 & 6 & 3 & 3 & 178 & 5 & 7 & \\
\hline \multicolumn{2}{|r|}{-} & & 146 & 30 & 5 & $\mathbf{0}$ & 1 & 182 & 1 & 3 & Controls \\
\hline
\end{tabular}

the remainder of the rheumatoid families. There were no definite radiological changes of rheumatoid arthritis in the families of those with Grade 3-4 rheumatoid arthritis and a negative test. There was, however, more radiological than clinical rheumatoid arthritis in the families of those with a positive sheep-cell test only, these having three times as much as the controls. The difference is not significant $(P=0 \cdot 08)$. There is, however, a very significant difference between the families of those with positive and negative sheep-cell tests, of whom 12 and 1 per cent. respectively had definite radiological evidence of rheumatoid arthritis $(P=<0 \cdot 01)$. In fact, the sheep-cell 
negative families had less than the controls. This might have been due to the large number of young people in the sero-negative families. When, however, those below 25 and over 65 years of age are removed from the rheumatoid family groups, the prevalence of radiological rheumatoid arthritis in the sero-positive and sero-negative families is 11 and 2 per cent. respectively and is thus still significant $(P=0.01)$.

Sheep-Cell Test.-The sheep-cell test similarly was positive in nearly three times as many of the rheumatoid relatives as of the controls (Table VI). The families of those with a negative sheep-cell test, however, showed no more positives than the controls. Relatives of the sero-positive cases on the other hand had four times as many $(P=<0.01)$. The families of propositi with a positive sheep-cell test without clinical disease had as many positives as the families of propositi with both clinical disease and a positive test. It should be noted that the difference between the rheumatoid families and controls is not limited to those with a titre of $1 / 32$ or more, but applies to all titres down to a level of $1 / 8$. When the relatives under 25 and over 65 years of age are removed from all groups, the proportion with a positive test in the sero-negative and sero-positive families becomes 8 and 20 per cent. respectively $(P=0 \cdot 06)$.

A.R.A. Classification.-As a composite assessment of all the main features of rheumatoid arthritis, the A.R.A. classification (Ropes, Bennett,
Cobb, Jacox, and Jessar, 1956) has been used (Table VII, opposite). This reflects the findings in the previous Tables, though the differences tend to be less striking. The families of sero-negative rheumatoids show the same proportion with probable and definite rheumatoid arthritis as the controls, whereas the families of sero-positive rheumatoids have twice as much. As with clinical rheumatoid arthritis, the positives in the sero-negative families are limited to the families of those with Grade 2 clinical rheumatoid arthritis, and the families of those with a positive sheep-cell test without clinical disease have fewer positives than those with both clinical and serological evidence of rheumatoid arthritis.

Osteo-Arthrosis.-A relationship between rheumatoid arthritis and osteo-arthrosis has been postulated from time to time, but was not confirmed in our studies of the 55 to 64 age group in Leigh (Kellgren and Lawrence, 1958). Difficulty may, however, have arisen from the opposing influence of two possible factors. On the one hand, the rheumatoid process may, by damaging articular cartilage predispose to degenerative change following minor trauma. On the other hand, it may, by preventing exercise, protect the joint from normal traumatic exposure. Where the rheumatoid process is severe, the latter effect will, except in the most hardy and determined patients, predominate. Where it is mild, and particularly if it is sub-clinical, the former effect will be more important. The present

TABLE VI

SHEEP-CELL AGGLUTINATION TEST TITRE DISTRIBUTION IN RELATIVES OF PROPOSITI AND IN CONTROLS

\begin{tabular}{|c|c|c|c|c|c|c|c|c|c|c|c|c|c|c|}
\hline \multicolumn{3}{|c|}{ Propositi } & \multicolumn{11}{|c|}{ Sheep-cell Agglutination Test Titre } & \multirow{3}{*}{$\begin{array}{c}\text { Group } \\
\text { Examined } \\
\text { for } \\
\text { Comparison }\end{array}$} \\
\hline \multirow{2}{*}{$\begin{array}{c}\text { Sheep-cell } \\
\text { Agglutina- } \\
\text { tion } \\
\text { Test }\end{array}$} & \multirow{2}{*}{$\begin{array}{c}\text { Clinical } \\
\text { Rheumatoid } \\
\text { Arthritis } \\
\text { Grading }\end{array}$} & & \multicolumn{4}{|c|}{ Negative } & \multicolumn{4}{|c|}{ Positive } & \multirow{2}{*}{$\begin{array}{l}\text { Total } \\
\text { Tested }\end{array}$} & \multirow{2}{*}{$\begin{array}{c}\text { Not } \\
\text { Tested }\end{array}$} & \multirow{2}{*}{$\begin{array}{c}\text { Positives } \\
\text { (Percentage } \\
\text { of Total } \\
\text { tested) }\end{array}$} & \\
\hline & & No. & $1 /<4$ & $1 / 4$ & $1 / 8$ & $1 / 16$ & $1 / 32$ & $1 / 64$ & $1 / 128$ & $1 / 256$ & & & & \\
\hline \multirow{2}{*}{ Negative } & $\begin{array}{l}\text { Moderate or } \\
\text { Severe }\end{array}$ & 8 & 16 & 2 & 2 & $\mathbf{0}$ & 1 & 1 & 0 & $\mathbf{0}$ & 22 & 1 & \multirow{2}{*}{$\left.\begin{array}{l}9 \\
5\end{array}\right\} 6$} & \multirow{7}{*}{$\begin{array}{l}\text { Relatives } \\
\text { of } \\
\text { Propositi }\end{array}$} \\
\hline & Minimal & 21 & 27 & 11 & 18 & 5 & 1 & $\mathbf{0}$ & 1 & 1 & 64 & 1 & & \\
\hline \multirow{3}{*}{ Positive } & $\begin{array}{c}\text { Moderate or } \\
\text { Severe }\end{array}$ & 10 & 11 & 4 & 3 & 2 & 3 & 2 & 1 & 1 & 27 & 0 & 26 & \\
\hline & Minimal & 4 & 11 & 1 & 2 & 1 & 0 & 0 & 0 & 0 & 15 & 1 & 0 & \\
\hline & $\begin{array}{l}\text { None or } \\
\text { Doubtful ... }\end{array}$ & 21 & 25 & 10 & 3 & 2 & 8 & 3 & 0 & 1 & 52 & 0 & 23 & \\
\hline \multicolumn{2}{|c|}{ 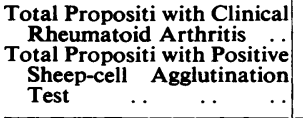 } & 35 & 47 & 15 & 25 & 5 & 11 & 5 & 1 & 2 & 128 & 3 & 20 & \\
\hline \multirow{2}{*}{\multicolumn{2}{|c|}{ Total }} & 64 & 90 & 28 & 28 & 10 & 13 & 6 & 2 & 3 & 180 & 3 & 13 & \\
\hline & & & 100 & 35 & 23 & 9 & 6 & 0 & 1 & 2 & 176 & 7 & 5 & Controls \\
\hline
\end{tabular}


TABLE VII

AMERICAN RHEUMATISM ASSOCIATION CLASSIFICATION APPLIED TO RELATIVES OF PROPOSITI AND TO CONTROLS

\begin{tabular}{|c|c|c|c|c|c|c|c|c|c|c|}
\hline \multicolumn{4}{|c|}{ Propositi } & \multicolumn{6}{|c|}{ A.R.A. Grading } & \multirow{2}{*}{$\begin{array}{c}\text { Group } \\
\text { Examined } \\
\text { for } \\
\text { Comparison }\end{array}$} \\
\hline $\begin{array}{l}\text { Sheep-cell } \\
\text { Agglutina- } \\
\text { tion Test }\end{array}$ & $\underset{\mathrm{Gr}}{\mathrm{Cl}}$ & $\begin{array}{l}\text { al } \\
\text { Arthritis } \\
\text { ng }\end{array}$ & No. & None & Possible & Probable & Definite & Total & $\begin{array}{c}\text { Probable + Definite } \\
\text { (Percentage of } \\
\text { total) }\end{array}$ & \\
\hline \multirow{2}{*}{ Negative } & Moderate & Severe ... & 8 & 18 & 5 & $\mathbf{0}$ & $\mathbf{0}$ & 23 & $\mathbf{0}$ & \multirow{7}{*}{$\begin{array}{l}\text { Relatives } \\
\text { of } \\
\text { Propositi }\end{array}$} \\
\hline & Minimal & $\ldots \quad \ldots$ & 21 & 56 & 5 & 4 & 0 & 65 & 6 & \\
\hline \multirow{3}{*}{ Positive } & Moderate & Severe ... & 10 & 18 & 4 & 2 & 3 & 27 & 18 & \\
\hline & Minimal & $\cdots \quad \ldots$ & 4 & 13 & 1 & 2 & 0 & 16 & 13 & \\
\hline & None or I & ibtful $\quad$. & 21 & 42 & 7 & 2 & 1 & 52 & 6 & \\
\hline \multicolumn{3}{|c|}{$\begin{array}{l}\text { Total Propositi with Clinical Rheuma- } \\
\text { toid Arthritis . } \\
\text { Total Propositi with Positive Sheep-ceil } \\
\text { Agglutination Test } \ldots \text {.. }\end{array}$} & $\begin{array}{l}43 \\
35\end{array}$ & $\begin{array}{r}105 \\
73\end{array}$ & 12 & 6 & 4 & 131 & 11 & \\
\hline \multirow[t]{2}{*}{ Tota } & . & $\cdots$ & 64 & 147 & 22 & 10 & 4 & 183 & 8 & \\
\hline & - & & & 152 & 22 & 7 & 2 & 183 & 5 & Controls \\
\hline
\end{tabular}

TABLE VIII

PREVALENCE OF RADIOLOGICAL MULTIPLE OSTEO-ARTHROSIS IN RELATIVES OF PROPOSITI AND IN CONTROLS

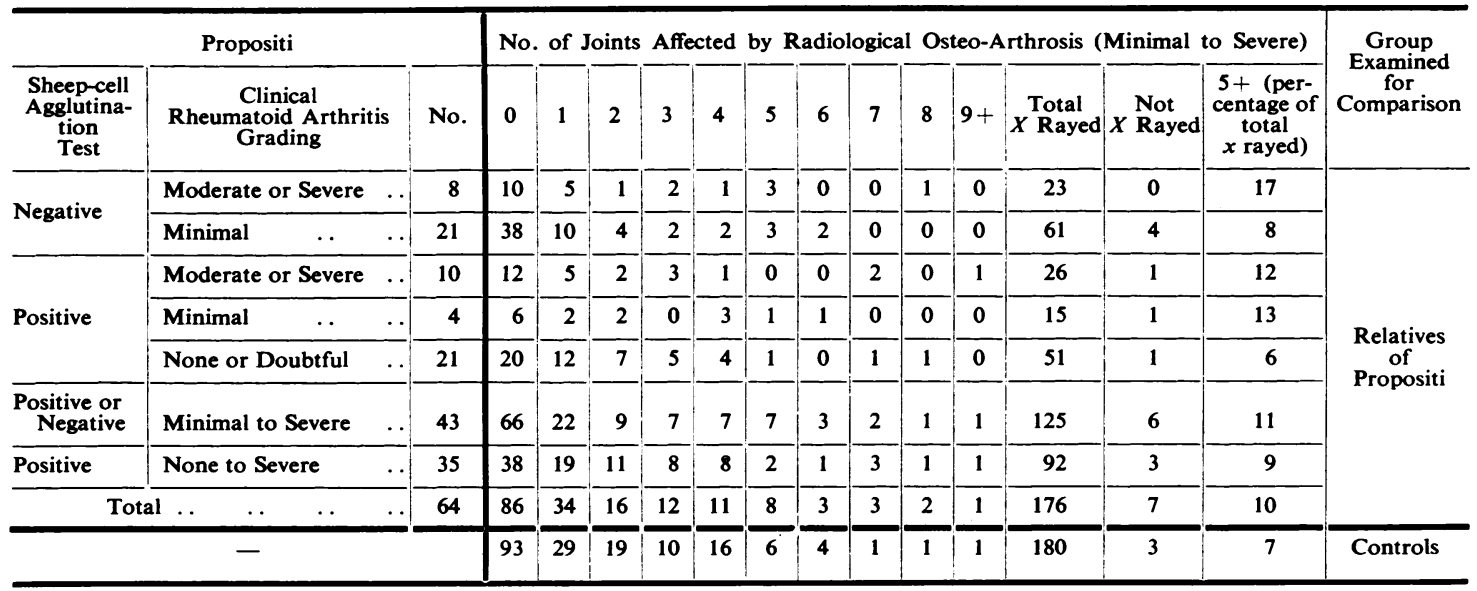

study offers a useful opportunity to test the latter hypothesis. If it is correct a higher proportion of persons with osteo-arthrosis, and particularly with multiple osteo-arthrosis, would be expected in the rheumatoid families. As shown in Table VIII this is not the case, the sero-positive families having no more multiple osteo-arthrosis than the seronegative families and not significantly more than the controls. Only the families of moderate to severe sero-negative propositi have more than twice as much multiple osteo-arthrosis as the controls, but the numbers in this group are too small to give a significant difference.
Sheep-Cell Titre in Propositi.-So far the propositi have been divided into those having a positive test at a serum dilution of $1 / 32$ and those not producing agglutination at this level. In view of the somewhat raised prevalence of rheumatoid arthritis in the families of those with Grade 2 clinical rheumatoid arthritis and a negative test, it may be considered whether in minimal rheumatoid arthritis a lower titre may not exclude the patient from the seropositive group. It should be borne in mind that only a single test was made on each propositus, so that no allowance is made for transient fluctuations in the titre. 
TABLE IX

PREVALENCE OF CLINICAL, RADIOLOGICAL, AND SEROLOGICAL RHEUMATOID ARTHRITIS IN RELATIVES OF PROPOSITI IN RELATION TO SHEEP-CELL AGGLUTINATION TEST TITRE IN PROPOSITI

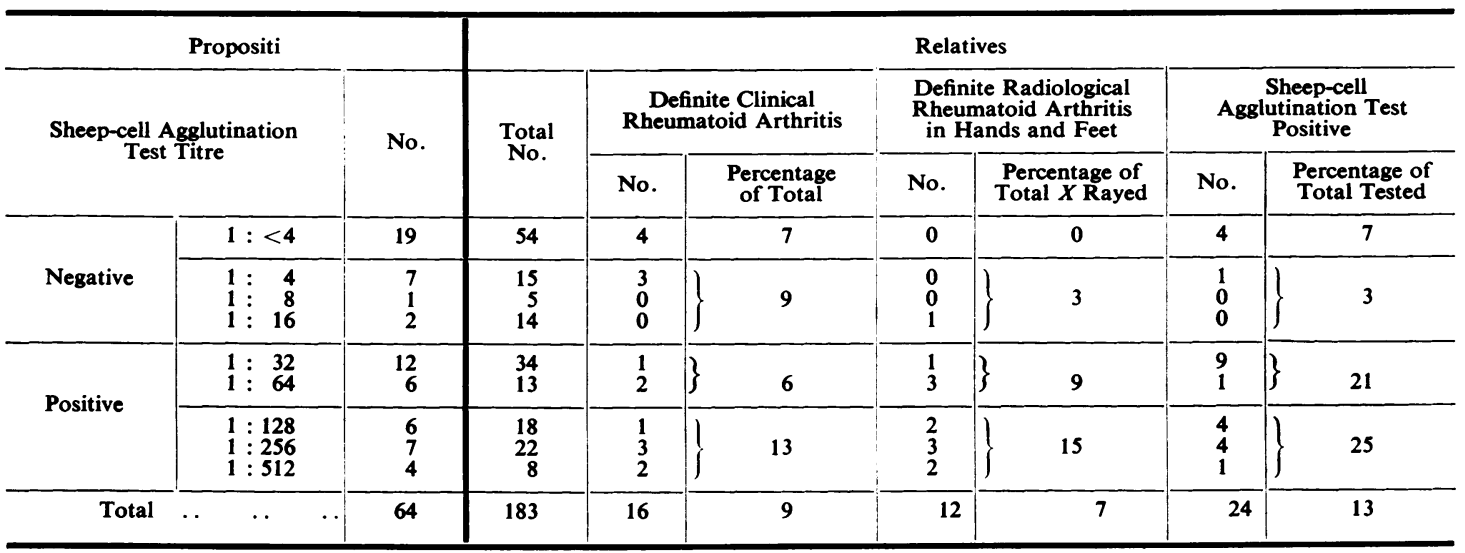

In Table IX they are classified by sheep-cell titre, regardless of the presence of clinical disease. The families of those with a titre of $1: 4$ to $1: 16$ showed no constant difference from the families without agglutination. Above this level there was an increase of both radiological and serological evidence of rheumatoid arthritis in relatives. At a titre of $1: 128$ and above, there was a further increase of radiological and serological positives and clinical disease was also more prevalent. The differences between the last two levels, however, are small and may well be due to chance variation in the families.

\section{Discussion}

From the findings in this study it is clear that there is a strong familial trend in rheumatoid arthritis. It is first necessary to consider whether this is hereditary or environmental. If the latter, it would be expected that unrelated members of the rheumatoid households would show a high prevalence. Of the spouses of the propositi in this study seventeen were examined. None of these showed clinical or radiological evidence of rheumatoid arthritis and only one had a positive sheep-cell test. The prevalence of positive tests in the population of this age group was 5 per cent., so that a single positive result might well be due to chance. An examination of the material available in the rheumatic complaints study made in Leigh in 1950 , in which all persons over 15 years of age in 1,393 households were seen, revealed the same prevalence of rheumatoid arthritis in the households of those with rheumatoid arthritis as in the total sample. It would thus seem unlikely that home environment plays an important part or that it could explain the high prevalence which has been discovered in the relatives of persons with rheumatoid arthritis in this study. On both radiological and serological grounds there is sharp division between the families of sero-negative and sero-positive propositi. Only on the clinical assessment do the sero-negative families have more rheumatoid arthritis than the controls, and of these only the families of Grade 2 propositi contain persons with rheumatoid arthritis. Of the seven relatives graded as having definite clinical rheumatoid arthritis in this group, one had moderately severe disease confirmed radiologically. The remaining six had minimal signs, generally with symptoms in the past only and without radiological or serological confirmation. All had radiological evidence of osteo-arthrosis in one or more groups of joints, and it may be considered whether confusion has arisen between rheumatoid arthritis and primary generalized osteo-arthrosis in the relatives and possibly also in the propositi, who similarly all had radiological evidence of osteoarthrosis in one or more joints. It should be mentioned that there is evidence of a strong hereditary factor in primary generalized osteo-arthrosis (Kellgren and Lawrence, 1958). The other possibility, that the propositi had sero-positive disease which had become sero-negative, appeared unlikely as a marginal titre was encountered only once and most had a negative test even with undiluted serum.

Determination of the mode of inheritance presents some difficulty owing to the low expressivity of the disease in the lower age groups. Though a positive sheep-cell test may serve as a useful index of the presence of the abnormal gene, a negative test does 
not indicate its absence, since the test is not positive at birth but develops in later life, commonly with or after the onset of symptoms. For example, in those aged 65 or over in the sero-positive families, a positive sheep-cell agglutination test occurred in 38 per cent. compared with 16 per cent. in those under 65 . Of the controls aged 65 or over, 13 per cent. had a positive test. If this number is deducted from the sero-positive families, a proportion of 25 per cent. with a positive test remains. This is the proportion of siblings which would be expected to show the abnormality if the condition were a recessive. If the 13 per cent. of controls with a positive test in this age group represent the total persons who are homozygous for the abnormality, the gene frequency would be $\sqrt{0 \cdot 13}=0.36$ or roughly one in three of the population. This is based on the assumption that all those who are homozygous for the abnormal gene will have developed a positive sheep-cell agglutination test by the age of 65 years.

Cobb, Warren, Thompson, and Ciocco (1954) have produced evidence that morning stiffness is an important manifestation of rheumatoid arthritis. It is of interest, therefore, to investigate the frequency of this symptom in rheumatoid families and in particular to make a comparison between seropositive and sero-negative families. With this in view a question on morning stiffness was included in the examination of all respondents. In fact, only the families of those with clinical rheumatoid arthritis plus a positive sheep-cell agglutination test had appreciably more morning stiffness than the controls (Table X). Of the members of these families, 35 per cent. complained of morning stiff- ness compared with 25 per cent. in the controls, and 20 per cent. in the sero-negative families $(P=0 \cdot 07)$. Though not conclusive, these figures suggest that morning stiffness is a feature rather of sero-positive rheumatoid arthritis than of rheumatoid disease as a whole. It should be noted that both morning stiffness and clinical rheumatoid arthritis are less frequent in the relatives of sero-positive propositi without clinical disease than in the relatives of those with clinical rheumatoid arthritis. The possibility that a second allele may be concerned with the clinical manifestations of the disease cannot, therefore, be excluded.

\section{Summary}

(1) A series of 183 relatives (parents, siblings, and children) of persons with either clinical rheumatoid arthritis or a positive sheep-cell test was examined clinically, radiologically, and serologically, and compared with a control group matched by age and sex. The propositi and the controls were taken from random samples of the population of a Lancashire town.

(2) Clinical, radiological, and serological evidence of rheumatoid arthritis was encountered four times more frequently in the families of those with a positive sheep-cell test than in the controls. The families of sero-negative propositi showed no more radiological or serological evidence of the disease than the controls, but had more clinical rheumatoid arthritis. This clinical disease was of minimal severity and was found only in the relatives of propositi who had themselves minimal clinical rheumatoid arthritis. Both relatives and propositi

TABLE X

PREVALENCE OF MORNING STIFFNESS IN RELATIVES OF PROPOSITI AND IN CONTROLS

\begin{tabular}{|c|c|c|c|c|c|c|c|c|}
\hline \multicolumn{4}{|c|}{ Propositi } & \multicolumn{4}{|c|}{ Morning Stiffness } & \multirow[b]{2}{*}{$\begin{array}{l}\text { Group } \\
\text { Examined } \\
\text { for } \\
\text { Comparison }\end{array}$} \\
\hline $\begin{array}{l}\text { Sheep-cell } \\
\text { Agglutination } \\
\text { Test }\end{array}$ & $\begin{array}{r}\text { Clin } \\
\text { Rrad }\end{array}$ & $\begin{array}{l}\text { al } \\
\text { Arthritis } \\
\text { ng }\end{array}$ & No. & Present & $\begin{array}{l}\text { Total } \\
\text { Stated }\end{array}$ & $\begin{array}{c}\text { Not } \\
\text { Stated }\end{array}$ & $\begin{array}{l}\text { Present } \\
\text { (percentage of } \\
\text { total stated) }\end{array}$ & \\
\hline \multirow{2}{*}{ Negative } & Moderate & Severe .. & 8 & 6 & 21 & 2 & 29 & \multirow{7}{*}{$\begin{array}{l}\text { Relatives } \\
\text { of } \\
\text { Propositi }\end{array}$} \\
\hline & Minimal & . $\quad \ldots$ & 21 & 11 & 64 & 1 & 17 & \\
\hline \multirow{3}{*}{ Positive } & Moderate & Severe ...! & 10 & 10 & 26 & 1 & 38 & \\
\hline & Minimal & $\cdots \quad \cdots$ & 4 & 5 & 15 & 1 & 33 & \\
\hline & None or D & ubtful & 21 & 11 & 51 & 1 & 22 & \\
\hline \multicolumn{3}{|c|}{$\begin{array}{l}\text { Total Propositi with Clinical Rheumatoid } \\
\text { Arthritis } \\
\text { Total Propositi with Positive Sheep-cell } \\
\text { Agglutination Test } \ldots \\
\text {.. }\end{array}$} & 35 & 26 & 125 & 3 & 28 & \\
\hline Total & $\cdots$ & $\cdots$ & 64 & 43 & 177 & 6 & 24 & \\
\hline & 一 & & & 45 & 177 & 6 & 25 & Controls \\
\hline
\end{tabular}


in this group had a high prevalence of multiple osteo-arthrosis.

(3) The mode of inheritance of sero-positive rheumatoid arthritis is discussed.

We wish to express our thanks to Professor J. H. Kellgren for advice on the planning and execution of this survey and to the people of Leigh for generously taking part. We are indebted to the Pneumoconiosis Research Unit (Cardiff) for technical assistance and the loan of equipment, and to Prof. J. S. Penrose and Mr. M. G. Bulmer for advice on the genetic aspects.

\section{REFERENCES}

Barter, R. W. (1952). Ann. rheum. Dis., 11, 39

Cobb, S., Warren, J., Thompson, D., and Ciocco, A. (1954). Penn. med. J., 57, 37

De Blecourt, J. J. (1958). Ann. rheum. Dis. (in preparation).

Falls, H. F. (1953). In "Clinical Genetics", ed. A. Sorsby, p. 282. Butterworth, London.

Kellgren, J. H., and Lawrence, J. S. (1956). Ann. rheum. Dis., 15, 1. (1957). Ibid., 16, 494.

Kroner. Quoted by Falls (1953) as having been quoted by Weitz (1936).

Lewis-Faning, E. (1950). Ann. rheum. Dis., 9, Suppl.

Miall, W. E. (1955). Ibid., 14, 150.

Papp, J., and Tepperberg, K. (1937). Quoted by Falls (1953).

Ropes, M. W., Bennett, G. A., Cobb, S., Jacox, R., and Jessar, R. A. (1956).' Bull. rheum. Dis., 7, 121

Kaufmann and Scheerer (1928). Quoted by Falls (1953).

Short, C. L., Abrams, N. R., and Sartwell, P. E. (1952). "Rheumatic Diseases: based on the Proceedings of the VII International Congress on Rheumatic Diseases", p. 47. Saunders, Philadelphia. Quoted by Falls (1953).

Stecher, R. M., Solomon, W. M., and Wolpaw, R. (1952). Ibid., p. 66. Quoted by Falls (1953).

\section{Etudes génétiques de l'arthrite rhumatismale}

\section{RÉSUMÉ}

(1) Une série de 183 parents (pères, mères, frères, soeurs et enfants) des personnes, soit atteintes d'arthrite rhumatismale clinique, soit accusant une réaction d'agglutination de globules de mouton positive, furent examinés du point de vue clinique, radiologique et sérologique, et comparés à un groupe de témoins d'âge et de sexe équivalent. Les sujets et les témoins furent choisis au hasard parmi les habitants d'une ville de Lancashire.

(2) Preuves cliniques, radiologiques et sérologiques d'arthrite rhumatismale furent rencontrées quatre fois plus souvent dans les familles des sujets ayant une réaction d'agglutination positive que chez les témoins. Dans les familles des sujets séro-négatifs la fréquence des signes radiologiques ou sérologiques de la maladie ne fut pas supérieure à celle des témoins, mais l'arthrite rhumatismale clinique fut plus fréquente. Cette arthrite clinique fut peu grave et n'existait que chez des parents des sujets eux mêmes atteints d'une arthrite très benigne. Dans ce groupe, aussi bien chez les parents que chez les sujets, on trouva beaucoup de cas d'ostéo-arthrose multiple.

(3) On discute le mode de transmission héréditaire de l'arthrite rhumatismale séro-positive.

\section{Estudios genéticos de la artritis reumatoide Sumario}

(1) Una serie de 183 parientes (padres, hermanos e hijos, de ambos sexos) de sujetos sea con artritis reumatoide clínica, sea con una reacción de aglutinación de glóbulos de oveja positiva, fué examinada clínica, radiológica y serológicamente y comparada con un grupo de testigos de edad y sexo correspondientes. Los sujetos y los testigos fueron escogidos al azar en una ciudad de Lancashire.

(2) Pruebas clínicas, radiológicas y serológicas de artritis reumatoide fueron encontradas cuatro veces más a menudo en las familias de los sujetos con la reacción de aglutinación positiva que en los testigoso En las familias de los sujetos sero-negativos, la frecuencia de los signos radiológicos o serológicos de la enfermedadô no fué superior a la en los testigos, pero la artritis reuma-toide clínica fué más frecuente. Esta artritis clínica fué benigna y existió sólo en los parientes de los sujetos cuya artritis fué también benigna. En este grupo, tanto en los parientes como en los sujetos, hubo muchos casos de ósteo-artrosis multiple.

(3) Se discute el modo de transmisión hereditaria de la artritis reumatoide sero-positiva. 